\title{
How big is best? Various nest box sizes and their acceptance by Muscardinus avellanarius (Rodentia: Gliridae)
}

\author{
Jak velká je ta nejlepší? Různé hnízdní budky a jejich přijetí plšíkem lískovým \\ (Muscardinus avellanarius) (Rodentia: Gliridae)
}

\author{
Carina HEBERER ${ }^{1}$, Bettina KOPPMANN-RUMPF ${ }^{1,2} \&$ Karl-Heinz SCHMIDT ${ }^{1}$ \\ ${ }^{1}$ Ecological Research Centre Schluechtern, Georg-Flemmig-Str. 5, D-36381 Schluechtern, Germany; \\ ch@forschung-oefs.de \\ ${ }^{2}$ Goethe University Frankfurt, D-60323 Frankfurt am Main, Germany
}

received on 11 February 2018

\begin{abstract}
The hazel dormouse (Muscardinus avellanarius) can be found in nest boxes intended for birds and dormice throughout its distributional range. To minimize competition with other potential nest box inhabitants such as the edible dormouse (Glis glis) and hole-nesting passerines like the blue tit (Cyanistes caeruleus), we successfully tested nest boxes with a $21 \mathrm{~mm}$ entrance hole in previous studies. The only competing species still able to pass through the entrance hole were the wood mouse (Apodemus sylvaticus) and possibly the yellow-necked mouse (Apodemus flavicollis). To further optimize the nest boxes we tested whether their internal space might be important for selection by the hazel dormouse. Starting in 2015, we set up groups of four wooden nest boxes varying in base area $(50 \times 50 \mathrm{~mm}, 60 \times 60 \mathrm{~mm}, 70 \times 70 \mathrm{~mm}$ and $80 \times 80 \mathrm{~mm}$, respectively) with $21 \mathrm{~mm}$ entrance holes. The nest boxes were placed in an identical array at 15 stations spaced at intervals of $30 \mathrm{~m}$ along a hedgerow. By doing regular nest box checks and documenting all species found we investigated which nest box types were used most often by the hazel dormouse in order to detect possible preferences. So far, the data show a more intensive use of the nest boxes that provided the largest internal space, i.e. $80 \times 80 \mathrm{~mm}$.
\end{abstract}

Key words. Nest boxes, nest box sizes, preferences, entrance hole, competition.

\section{INTRODUCTION}

The hazel dormouse (Muscardinus avellanarius) builds and uses ball-shaped nests that can be found from ground level to the tops of trees (EDEN 2009). Nests may be built in the vegetation or in cavities of hollow trees that provide secure nesting places (MORRIS 2004). Furthermore, the species is known to accept nest boxes designed either for dormice or for birds. Nest boxes may be advantageous for reproduction, having a positive effect on the survival rate of the juveniles in poor weather conditions (JUŠKAITIS 2014).

When using nest boxes, the hazel dormouse has to face competing species such as hole-breeding passerines, e.g. great tit (Parus major) and blue tit (Cyanistes caeruleus). The results of dormouse-bird encounters in nest boxes are known to be diverse. In the course of our long-term

This contribution has been presented at the 10th International Dormouse Conference held at the University of Liège, Belgium, on 11-15 September 2017 
study on hole-breeding passerines and other nest box users over 50 years, interactions ranged from peaceful coexistence in the same nest box, the dormouse using the lower layers of the tit nests, to predation on bird eggs by the dormouse. Egg predation was likewise detected by various authors, e.g. JuŠKaITIS (1995) and MorRis (2004). Dormice can also be expelled (GATTER \& SCHÜTT 1999) or killed by tits (JUŠKAITIS \& BÜCHNER 2010). The hazel dormouse avoids nest boxes containing old tit nests (JUŠKAITIS \& BüCHNER 2010) as they may be infested with fleas (Peus 1953). When confronted with the odour of edible dormouse (Glis glis) nests, the reaction of the hazel dormouse is avoidance (ZAYTSEVA \& NovAKOWSKI 2012). This explains its general absence from nest boxes containing such nests. When encountering individuals of the edible dormouse in a nest box, the hazel dormouse is driven out (ADAMík \& KRÁl 2008) and its juveniles can be killed (JUŠKAITIS \& BüCHNER 2010).

Other superior competitors for nest boxes are the wood mouse (Apodemus sylvaticus), the yellow-necked mouse (Apodemus flavicollis) and the bank vole (Clethrionomys glareolus), which were all found to pass through similar and even smaller entrances than the hazel dormouse (Scherbaum-Heberer et al. 2012, Verbeylen 2017). The same is true for insects whose size enables them to pass through even very small holes.

In the course of our long-term study (38 years), we observed that due to elevated temperatures in spring, great and blue tits have advanced the beginning of egg-deposition by one week while the edible dormouse advanced its occupancy of nest boxes by up to seven weeks (KoPPMANN-Rumpf et al. 2003, Scherbaum-Heberer et al. 2011). Earlier appearance results in intensified competition for nest boxes. Hence creating a nest box whose measurements (i.e. base area and entrance hole) restrict access by as many competing species as possible may be advantageous to the hazel dormouse by reducing the pressure on this vulnerable species and providing shelter for reproduction and daytime sleep. Apart from this principal aim of the study, such nest boxes also helped to detect the presence of hazel dormice in a previously non-monitored area.

\section{MATERIAL AND METHODS}

The data used for this study were collected near the town of Schluechtern (50 $\left.19^{\prime} \mathrm{N} ; 9^{\circ} 28^{\prime} \mathrm{E}\right)$, Germany, in March-November 2015, March-November 2016 and March-June 2017. A total of 60 nest boxes were installed along a species-rich hedgerow, e.g. with hawthorn (Crataegus laevigata) and blackthorn (Prunus spinosa), surrounding an orchard.

Following the studies of JUŠKAITIS (2014), we used wooden nest boxes made of European larch (Larix decidua). To avoid nest box use by the edible dormouse the diameters of entrance holes should be less than $28 \mathrm{~mm}$ (JUŠKAITIS \& BüCHNER 2010). Blue tits are known to use entrance holes with a diameter of $26 \mathrm{~mm}$. To ensure the exclusion of both these species we chose entrance holes of $21 \mathrm{~mm}$. These could be accessed by hazel dormouse, even with litters (SCHERBAum-Heberer et al. 2012, 2017). A metal plate was placed around each entrance hole to prevent gnawing and hence changes in entrance hole size by nest box users.

The nest boxes were arranged in identical groups of four nest boxes of $27 \mathrm{~cm}$ height which varied in base area and hence internal space (type 1: $50 \times 50 \mathrm{~mm}$, type 2: $60 \times 60 \mathrm{~mm}$, type 3: $70 \times 70 \mathrm{~mm}$, type 4: $80 \times 80 \mathrm{~mm}$, respectively). This allowed for the minimal diameter of dormouse nests which is $4.5 \mathrm{~cm}$ (VILHEMSEN 1996). Boxes were placed next to each other and connected to a fence pole (Fig. 1). Hence the hazel dormouse had the same set of choices between four nest boxes at each of 15 fence poles throughout the sample area. They were set up at intervals of $30 \mathrm{~m}$ along the hedgerow close to the surrounding vegetation to ensure access by the dormice.

Nest box checks were carried out at least once per month from March until the disappearance of the hazel dormouse in the autumn, usually in November. All other species that had evidently used the nest 
box (i.e. individuals, nests, faeces) were registered. For the analysis, only dormouse nests (not findings of individuals or faeces) were included.

The total number of nest boxes containing dormouse nests for each nest box type were compared by applying Kruskal Wallis-test and Dunn's multiple comparisons test.

\section{RESULTS}

The nest boxes were almost exclusively used by the hazel dormouse. In the early part of each year almost no presence of wood mouse or yellow-necked mouse was detected. Most of their individuals and/or nests were not found until August/September with most findings in 2015 when mice were registered in a total of 14 nest boxes, either as late occupants of a previously empty nest box or using an existing dormouse nest. In 2016, no trace of mice was found whereas in June 2017 four nest boxes were occupied (a previously empty one in June and three nest boxes previously occupied by the hazel dormouse). In 2015, a bank vole was found in a nest box containing a hazel dormouse nest. Findings of insects in the nest boxes were scarce. In 2015, the European paper wasp (Polistes dominula) built its nest in one previously empty nest box. In 2016, one fully-developed nest of Saxon wasp (Dolichovespula saxonica) was found. Hence the dormice were rarely confronted with competing species when first entering the nest boxes in spring.

Throughout the whole study period, a total of 59 dormouse nests - either under construction or completed - were found in all four nest box types as shown in Fig. 2, with most findings registered for type 4 .

When comparing the number of dormouse nests in all four nest box types significant differences could be found (Kruskal-Wallis-test, $\mathrm{p}<0.05$ ): The number of nests in nest box type 4 was significantly higher than in type 1 (Dunn's multiple comparisons test, $\mathrm{p}<0.05$ ).

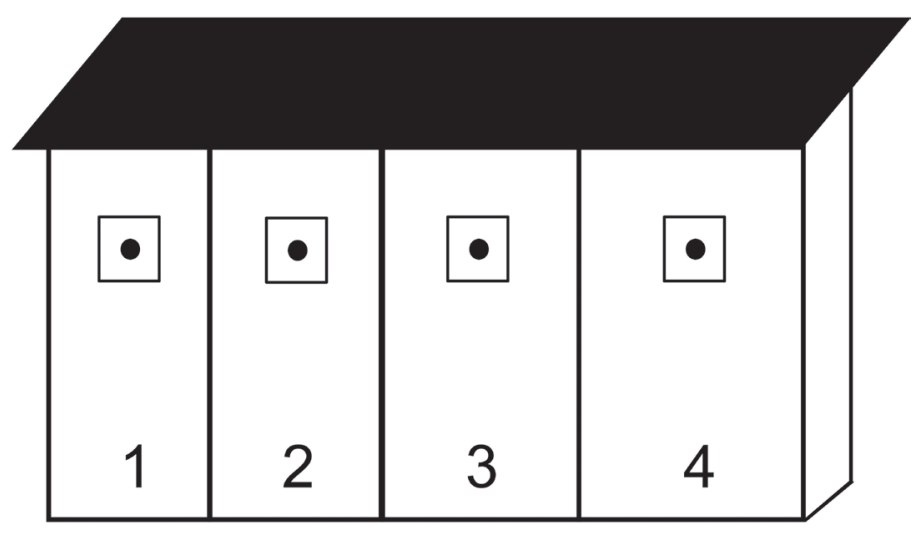

Fig. 1. Utilized combination of four nest boxes varying in base area (type 1:50×50 mm, type 2: $60 \times 60 \mathrm{~mm}$, type 3: $70 \times 70 \mathrm{~mm}$, type 4: $80 \times 80 \mathrm{~mm}$, respectively) (not true to scale).

Obr. 1. Použitá kombinace čtyř hnízdních budek lišících se plochou dna (typ 1: $50 \times 50 \mathrm{~mm}$, typ 2: $60 \times 60 \mathrm{~mm}$, typ 3: 70×70 mm, typ 4: $80 \times 80 \mathrm{~mm}$ ) (nikoliv ve vzájemném měřítku). 


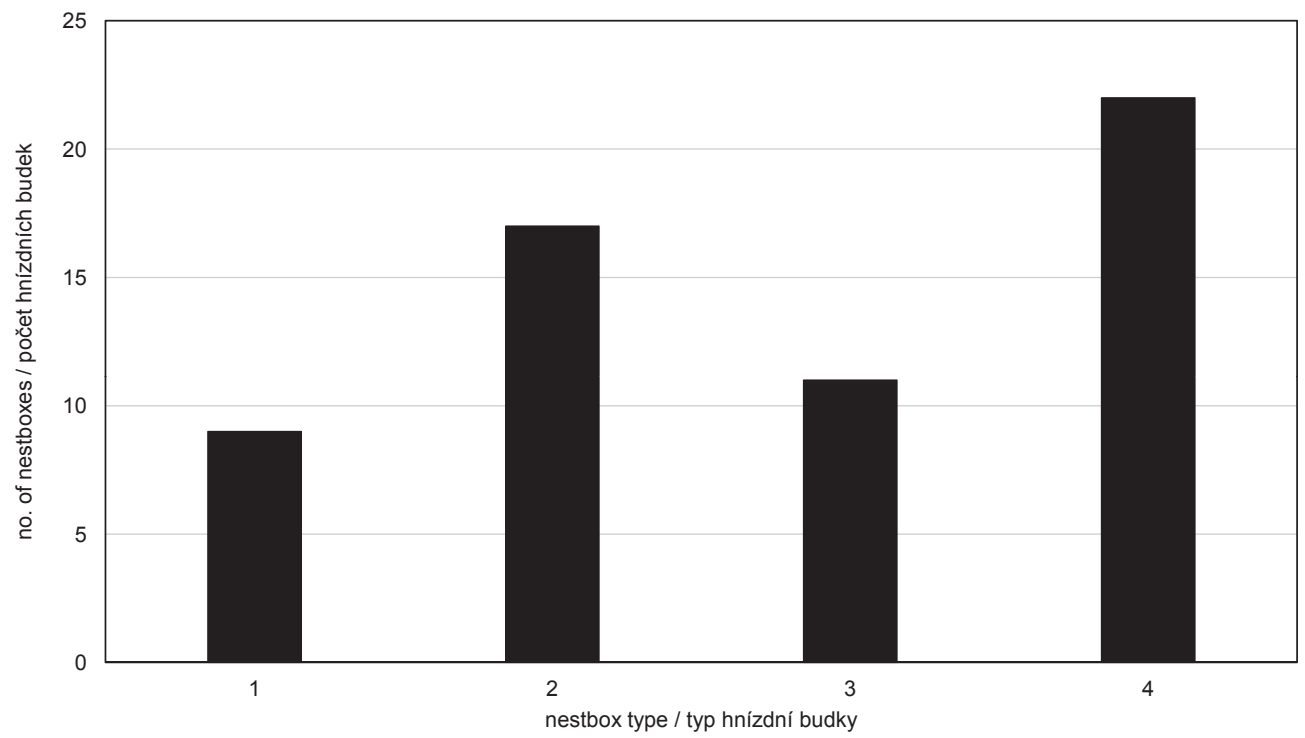

Fig. 2. Total number of hazel dormouse nests found for each nest box type (either under construction or completed, $\mathrm{n}=59$ ).

Obr. 2. Celkový počet hnízd (at' rozestavěných či dostavěných, n=59) plšíka lískového nalezených v jednotlivých typech hnízdních budek.

Excluding nests under construction and focusing on completed nests gave a total of 34 findings, with most nests present in nest box type 4 . However, the differences between the four nest box types were not significant (Kruskal-Wallis-test, $\mathrm{p}>0.05$ ).

\section{DISCUSSION}

Given the fact that other competing species were rarely found and occurred relatively late, the hazel dormouse could choose between the nest boxes provided on each fence pole early in the year. The results show a significantly greater use of nest boxes that provided the largest internal space in contrast to those offering the smallest measurements. Similar results were found by VAUGHAN (2001) who observed that for raising juveniles the hazel dormouse showed a significant preference towards nest boxes for birds with larger internal dimensions compared to nest boxes for dormice. However, no preferences could be detected in Lithuania when two different nest box sizes $(10 \times 10 \times 23 \mathrm{~cm}$ and $14 \times 14 \times 28 \mathrm{~cm})$ were offered (JUŠKAITIS 2014). In Sicily, when given a choice between two different and comparatively larger nest box sizes $(15 \times 15 \times 20 \mathrm{~cm}$ and $20 \times 20 \times 30 \mathrm{~cm}$ ), hazel dormice clearly preferred the smaller ones (SARÀ et al. 2005) whose inner dimensions correspond to the maximum diameters of hazel dormouse nests of up to $15 \mathrm{~cm}$ (VILHELMSEN 1996). This might explain why the species avoided the larger nest boxes in the study by SARÀ et al. (2005). When given the choice between four different sizes as in the present study, nest box type 4 was preferred, its base area being almost half the size of the species' maximum nest diameter. The largest nest box type also revealed the most completed 
nests, even though the numbers used did not significantly differ from the other nest box types. Hence there might be a size range with an upper limit around $8 \times 8 \mathrm{~cm}$ where larger nest boxes are clearly preferred. No such observations were made offering larger nest boxes whose diameters exceed $8 \mathrm{~cm}$ but not $15 \mathrm{~cm}$. To get a clearer picture of dormouse preferences, further data on different nest box sizes are required.

\section{SOUHRN}

Plšík lískový (Muscardinus avellanarius) využivá v celém svém areálu rozšíření různé typy hnízdních budek, určené prvotně jak pro ptáky, tak i pro plchy. Abychom dokázali co nejvíce omezit kompetici s dalšími potenciálními obyvateli budek, jako je plch velký (Glis glis), či dutinoví pěvci jako sýkora modřinka (Cyanistes caeruleus), otestovali jsme úspěšně v předešlých studiích hnízdní budky se vstupním otvorem o průměru $21 \mathrm{~mm}$. Jediným konkurenčním druhem, který byl stále schopen projít takovým vstupním otvorem, byla myšice křovinná (Apodemus sylvaticus) a možná i myšice lesní (Apodemus flavicollis). Pro další optimalisaci přednostního využití hnízdních budek plšíkem lískovým jsme zkoušeli, zda pro jejich výběr může být významná velikost a utváření vnitřního prostoru. Počínaje rokem 2015 jsme testovali sestavu čtyř dřevěných hnízdních budek se vstupními otvory o průměru $21 \mathrm{~mm}$, které se lišily plochou dna $(50 \times 50 \mathrm{~mm}, 60 \times 60 \mathrm{~mm}, 70 \times 70 \mathrm{~mm}$ a $80 \times 80 \mathrm{~mm})$. Budky byly umíst'ovány ve shodném poli na 15 stanovištích v rozestupech $30 \mathrm{~m}$ podél živého plotu. Pravidelnými kontrolami budek a dokumentací všech nalezených druhů jsme zkoumali, které jejich typy jsou nejčastěji používány plšíky lískovými, a tím určili jejich možné prostorové preference. Dosavadní údaje ukazují častější použití těch hnízdních budek, které poskytly plšíkům největší vnitřní prostor, tj. plochu dna $80 \times 80 \mathrm{~mm}$.

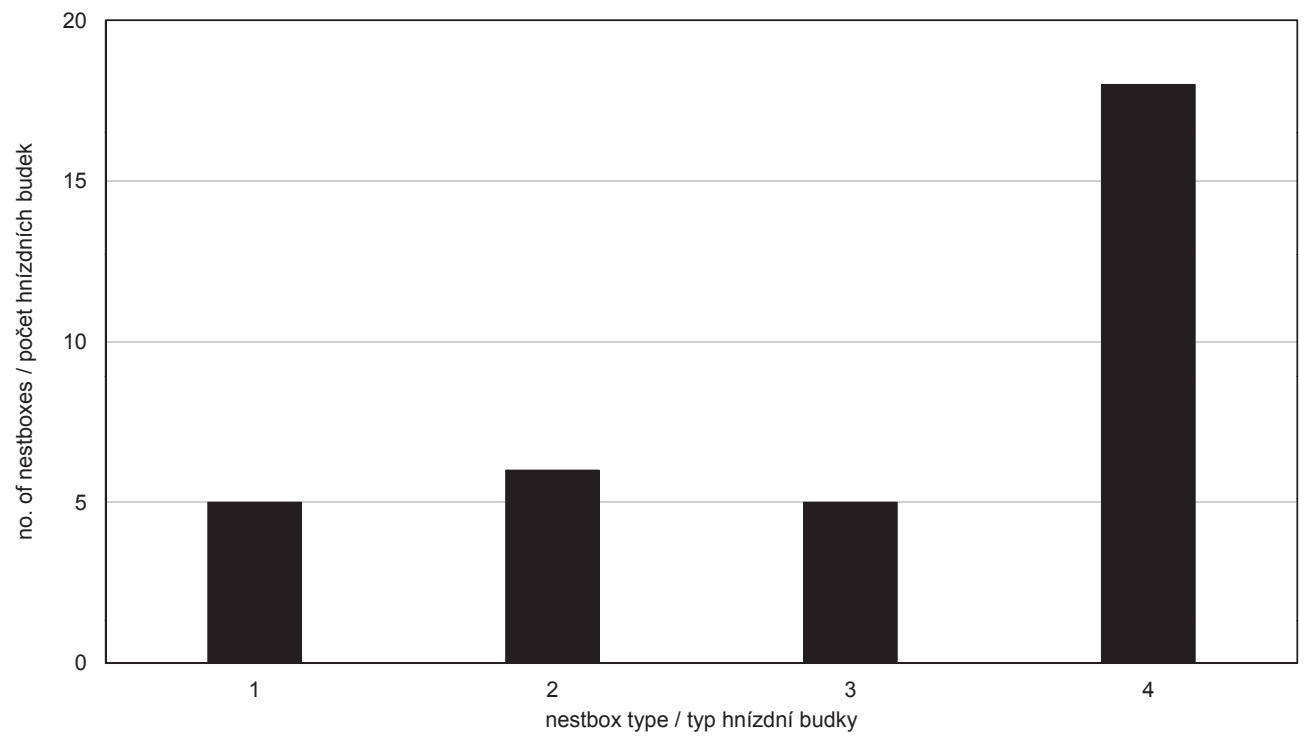

Fig. 3. Total number of completed hazel dormouse nests found for each nest box type $(n=34)$.

Obr. 3. Celkový počet dostavěných hnízd plšíka lískového nalezených v jednotlivých typech hnízdních budek $(n=34)$. 


\section{A c know le d gements}

For the revision of the text and valuable suggestions we would like to thank Pat MorRIs as well as Rimvydas JuŠKAITIS and Dave WilLIAMs.

\section{REFERENCES}

AdAMí P. \& KRÁL M., 2008: Nest losses of cavity nesting birds caused by dormice (Gliridae, Rodentia). Acta Theriologica, 53: 185-192.

Eden S., 2009: Living with Dormice. The Common Dormouse: Real Rodent or Phantom of the Ancient Wood? Papadakis Publisher, London \& Winterbourne, $128 \mathrm{pp}$.

GATteR W. \& SснÜтt R., 1999: Langzeitentwicklung der Höhlenkonkurrenz zwischen Vögeln (Aves) und Säugetieren (Bilche Gliridae, Mäuse Muridae) in den Wäldern Baden-Württembergs. Ornithologischer Anzeiger, 38: 107-130.

JUŠKAITIS R., 1995: Relations between common dormice (Muscardinus avellanarius) and other occupants of bird nest-boxes in Lithuania. Folia Zoologica, 44: 289-296.

JušKaitis R., 2014: The Common Dormouse Muscardinus avellanarius: Ecology, Population Structure and Dynamics. Nature Research Center, Vilnius, $196 \mathrm{pp}$.

JuŠKaItis R. \& BüChNER S., 2010: Die Haselmaus Muscardinus avellanarius. Die Neue Brehm-Bücherei, Band 670. Westarp Wissenschaften, Hohenwarsleben, 181 pp.

Koppmann-Rumpf B., Heberer C. \& Schmidt K.-H., 2003: Long term study of the reaction of the edible dormouse Glis glis (Rodentia: Gliridae) to climatic changes and its interactions with hole-breeding passerines. Acta Zoologica Hungarica, 49(Suppl. 1): 69-76.

Morris P., 2004: Dormice. Whittet Books, Stowmarket, 144 pp.

Peus F., 1953: Flöhe. Die Neue Brehm-Bücherei, Band 43. Akademische Verlagsgesellschaft Geest \& Portig, Leipzig, 42 pp.

Sarà M., Milazzo A., Falletta W. \& Bellia A., 2005: Exploitation competition between hole-nesters (Muscardinus avellanarius, Mammalia and Parus caeruleus, Aves) in Mediterranean woodlands. Journal of Zoology, London, 265: 347-357.

Scherbaum-Heberer C., Koppmann-Rumpf B., Dukova S., Janka H. \& Schmidt K.-H., 2011: Einfluss des Klimawandels auf die Höhlenkonkurrenz zwischen Vögeln, Kleinsäugern und Insekten. Abschlussbericht im Rahmen des Forschungsvorhabens INKLIM-A des Fachzentrums Klimawandel Hessen. URL: https:/www.hlnug.de/fileadmin/dokumente/klima/inklim_a/hoehlenkonkurrenz.pdf

Scherbaum-Heberer C., Koppmann-Rumpf B., Dukova S. \& Schmidt K.-H., 2012: Comparison of two nestbox types and their suitability for the common dormouse Muscardinus avellanarius. Peckiana, $\mathbf{8}$ : $167-172$.

Scherbaum-Heberer C., Koppmann-Rumpf B. \& Schmidt K.-H., 2017: Various nest box types and their suitability for the common dormouse Muscardinus avellanarius. Apodemus, 14: 49-54.

VAUGHAN G., 2001: "Dormousitis" - the sequel or should tit boxes be erected for mammals? Devon Birds, 54: 4-17.

VILHEMSEN H., 1996: The distribution, habitat requirements and nest sites of the hazel dormouse in Denmark. Pp.: 49-55. In: Müller-STIEss (ed.): Schläfer und Bilche. Tagungsbericht 1. Intern. Bilchkolloquium, St. Oswald 1990. Verein der Freunde des Ersten Deutschen Nationalparks Bayerischer Wald e.V., Neuschönau, 76 pp.

VERBEYLEN G., 2017: How small should the entrance be? Is it possible to let common dormice Muscardinus avellanarius enter nest boxes and exclude other species? Apodemus, 14: 44-48.

ZaYtseva H. \& NowaKowski W., 2012: The reactions of the common dormouse (Muscardinus avellanarius) and the yellow-necked mouse (Apodemus flavicollis) to the odour of nest. Peckiana, 8: 203-207. 